\title{
Biodegradation of Crude Oil-Polluted Soil by Bacterial Isolates from Nigeria
}

\author{
Umeaku Chinyelu Nkiru ${ }^{1}$, Emmy-egbe Ifeyinwa Orsla ${ }^{2}$, Ukoha Chinwe Clarice ${ }^{1}$, \\ Ezenwa Somadina Emmanuel ${ }^{1}$, Chris-Umeaku Chiamaka Ijeoma ${ }^{3}$ \\ ${ }^{1}$ Department of Microbiology, Chukwuemeka Odumegwu Ojukwu University, Anambra, Nigeria \\ ${ }^{2}$ Department of Biological Sciences, Chukwuemeka Odumegwu Ojukwu University, Anambra, Nigeria \\ ${ }^{3}$ Department of Biochemistry, Chukwuemeka Odumegwu Ojukwu University, Anambra, Nigeria
}

\section{Email address:}

chimeaku@yahoo.com (U. C. Nkiru)

\section{To cite this article:}

Umeaku Chinyelu Nkiru, Emmyegbe Ifeyinwa Orsla, Ukoha Chinwe Clarice, Ezenwa Somadina Emmanuel, Chris-Umeaku Chiamaka Ijeoma. Biodegradation of Crude Oil-Polluted Soil by Bacterial Isolates from Nigeria. Frontiers in Environmental Microbiology. Vol. 5, No. 1, 2019, pp. 14-28. doi: 10.11648/j.fem.20190501.13

Received: June 14, 2018; Accepted: August 7, 2018; Published: March 11, 2019

\begin{abstract}
Biodegradation of crude oil-polluted soils by bacterial isolates was carried out experimentally, to determine the ability of bacterial isolate to utilize and detoxify crude oil-polluted soils. Three soil samples were collected from crude oilpolluted sites of Owazangboko, Abia State, Aguleri-otu, Anambra State and Obi-igbo, Rivers State, Nigeria. Microbiological analysis and physico-chemical analysis were carried out in the Microbiology Laboratory of Chukwuemeka Odumegwu Ojukwu University, Uli. Physico-chemical analysis was carried out to determine the $\mathrm{pH}$, moisture content, water holding capacity and total organic carbon of the soil samples. Microbiological analysis was carried out using serial dilution and spread plate methods to determine the total viable count, enumeration of hydrocarbon utilizing bacteria (HUB) was done using vapour phase method on mineral salt agar monitored at the wavelength of $600 \mathrm{~nm}$ for 5 days. Adaptation test was carried out and monitored for 5 days using mineral salt broth containing $1 \mathrm{ml}$ and $2 \mathrm{ml}$ of sterile crude oil separately. A consortium of six effective isolates was taken for the biodegradation of the crude oil, which was monitored for 14 days. Biochemical tests were carried out on the isolates. Polymerase chain reaction (PCR) technique was used to confirm the identity of the isolates. Gas chromatographic flame ionization detector (GC-FID) was used to monitor the amount of the residual total petroleum hydrocarbon after the biodegradation study. Results of physic-chemical analysis showed; $\mathrm{pH}$ value of 3.7- 6.6, moisture content 1.6 - 4.4., water holding capacity $28.0-32.0$., total organic carbon $3.4-7.1$. Results of total viable count were in the range of $7.1 \times 10^{6}-5.9 \times 10^{10}$. Results of vapour phase method ranged from $0.16-0.66$. Adaptability test revealed values, $0.11-$ 0.54. Biochemical test results revealed Bacillus spp., Pseudomonas spp., Serratia spp., Micrococcus spp., Arthrobacter spp., Proteus spp., Shigella spp. PCR results gave the identity of the organisms to be Lysinibacillus spp. M2c, Serratia marcescens Mb4, Bacillus aerius TPM-23, Proteus mirabilis LS-3 and a new unidentified bacterium. TPH concentrations were in the range of $582.67 \mathrm{mg} / 1$ - $123.67 \mathrm{mg} / 1$ for Lysinibacillus spp. M2c and Serratia marcescens Mb4, $682.65-203.85 \mathrm{mg} / \mathrm{l}$ for Bacillus aerius TPM-23and $753.32 \mathrm{mg} / \mathrm{l}-324.77 \mathrm{mg} / 1$ for Proteus mirabilis LS-3 and the new unidentified bacterium. The effect of bacterial growth across the days showed a p-value of 0.000 less than the $\alpha$-value 0.01 , this concluded that the growth of the bacteria across the days was significant for both vapour phase test and adaptability test. From this study it is evident that Serratia marcescens Mb4 and Lysinibacillus spp. M2c could be used to effectively treat crude oil-polluted environment.
\end{abstract}

Keywords: Crude Oil, Soil, Microbiological, Physico-Chemical, Biodegradation, PCR, Gas Chromatographic

\section{Introduction}

Crude oil pollution has been considered a global concern to both humans and the environment. In Nigeria, there is an average of 300 oil spills every year [1]. Environmentalists consider the Niger Delta region of the country as one of the world's most polluted regions [35]. The Niger Delta region consists entirely of nine States which include Abia, Akwa Ibom, Bayelsa, Cross Rivers, Delta, Edo, Imo, Ondo and 
Rivers [2]. The Niger Delta region, the base of the Nigerian oil and gas industry, generates over 90 percent of the nation's foreign exchange earnings. Paradoxically, in spite of the increasing revenue from crude oil exploitation, the communities from which this resource flows in the Niger Delta continue to live in conditions of social deprivation and abject poverty.

All stages of oil exploitation impact negatively on the environment, and the greatest single intractable environmental problem caused by crude oil exploration in the Niger Delta region is oil spillage [40]. Apart from other anthropogenic emission sources, atmospheric pollution in the region is associated with emissions from flaring and venting of petroleum associated natural gas by petroleum industries $[13,25,34]$. Atmospheric contaminants from anthropogenic activities can be categorized into (i) gaseous pollutants, (ii) persistent organic pollutants, (iii) particulate matter and (iv) trace element and/or heavy metals [16]. Release of petroleum hydrocarbons into the environment, whether accidentally or due to anthropogenics activities, is a major cause of uncontrolled water and soil pollution [16], and may also contribute to regional atmospheric pollution [13].

Bioremediation is described as the use of living microorganisms or microbial processes to detoxify and degrade environmental pollution. In order words, it is a technology for removing pollutants from the environment thus restoring the original natural environment. Soil biological activities: microbial counts, soil respiration, soil biomass and enzymes activities can be used to ascertain the extent of bioremediation process of oil contaminated soil [22]. Diplock et al. [8], suggested that meeting a bioremediation end point could be used to evaluate and predict the bioremediation of a contaminated area. The biochemical potential for a contaminated soil to reach a target level is used to define the end point of the remediation process [4]. Quantification of the total culturable degrader population; an evaluation of hydrocarbon bioavailability and a measure of constraints to biodegradation are key parameters to predict the likely performance of a bioremediation strategy [32]. Lin et al. [21] used a bioprocess of bioaugmentation and biostimulation with a molecular monitoring microarray biochip integrated with land farming operation to effectively degrade approximately $70 \%$ and $63 \%$ of diesel oil and fuel oil respectively after a period of 28 days. The bioslurry assays yielded a total petroleum hydrocarbon (TPH) reduction efficiency of $57 \%$ and $65 \%$ in 28 days respectively, Radwan et al. [33], employed the technique of immobilizing oil degrading bacteria, nocardioforms and Acinetobacter in biofilms coating macroalgae to remediate noctadecane and phenanthrene while Kermanshahi et al. [19], used immobilized microbial cell airlift bioreactor for aerobic bioremediation of simulated diesel fuel contaminated groundwater. Gargouri et al. [11] used a continuously stirred tank bioreactor (CSTR) to optimize feasible and reliable bioprocess system to treat hydrocarbon-rich industrial wastewaters. The use of the mixed cultures in the studies demonstrated high degradation performance for hydrocarbons range $n$-alkanes (C10-C35).

These techniques for removing petroleum hydrocarbons in the soil are developed around strategies for delivering moisture, aeration and nutrients in order to optimize microbial activity and degradation of the pollutants $[3,17$, 36]. This process involves treating the contaminant at the site of the contamination and is divided into bioattenuation, biostimulation and bioaugmentation. A study has revealed the high potency of Pseudomonas strains in bioremediation of petrochemical waste-waters [26]. Typical groups of bacterial known for their ability to degrade hydrocarbon include: Micrococcus, Pseudomonas, Alcanivorax, Microbulbifer and Cellulomonas. Hexadecane was degraded by Pseudomonas putida, Rhodococcus erthroplolis and Bacillus thermoleoovorans [1].

The long term aim of bioremediation designs is to present a cost effective strategy which will help to reduces pollutants to a level reasonably and practicably possible.

\subsection{Statement of the Problem}

Despite the availability and use of advanced technology in the petroleum industry, various forms of accidents such as blow-outs of production wells, explosions and pipeline rupture still occur, which are worsened by vandalization of oil installations and pipelines [14, 31] Irrespective of the numerous environmental laws enacted to protect the environment, gas flaring for example has also continued despite the Nigerian government's directive to end flaring by 2010. The Niger delta region claims that the activities of the oil companies instead of improving have impoverished its people by causing a serious decline in their marine and agricultural resources, which constitute their economic main stay. Since the latest escalation of violence, hundreds of people have been killed in clashes between militants and government security forces. Armed gangs have carried out numerous attacks on oil facilities kidnapping many oil workers and ordinary Nigerians for ransom. The Ogoni, Ijaw and other people in the Niger Delta, those who have been affected for decades have been trying to stand up for themselves, their environment and their basic human and economic rights. There is an urgent need to look into the ugly situation faced by the people of this region, to ensure environmental conservation of the Niger Delta by using microorganism to bioremediate their polluted environment. The goal of this research is to establish the ability of bacterial isolates to utilize and detoxify crude oil contaminated soil.

\subsection{Study Area}

The Niger Delta is described as a unique ecological zone by virtue of its size and geophysical configuration [23]. It is one of the world's largest wetlands covering an area of approximately $70,000 \mathrm{~km}$. Located in the South-South geopolitical region of Nigeria. It lies between latitude $4^{\circ}$ and $6^{\circ}$ North of the equator and longitude $5^{\circ}$ and $7^{\circ}$ East of Greenwich. It stretches from the Benin river in the West to 
Bonny river in East, while in land, it begins a few miles below Aboh at a point where river Niger splits into river Nun and Forcados into the Atlantic West at the South, stretching over 257,495 metres[15]. The region consists entirely of nine States which include Rivers, Bayelsa, Cross Rivers, AkwaIbom, Delta, Edo, Ondo, Abia, and Imo [2].

\subsection{Scope}

This study has been able to examine crude oil-polluted soil samples from Abia, Anambra and Rivers States of Nigeria. The biodegradation studies were conducted from September, 2016 to May, 2017.

\section{Materials and Method}

\subsection{Sample Collection}

Methods of Wood [41] were used in this study. Three composite soil samples were collected from three different locations of crude oil contamination. The locations include: Owazangboko, Ukwa west in Abia, Aguleriotu in Anambra and Obi-igbo, Oyigbo in River State. One soil sample was collected from a non-contaminated site in Awka, Anambra State, as control. Clean shovel was used to dig about $20 \mathrm{~cm}$ of the soil before sterile soil auger was used to collect the contaminated soil samples. Collected soil samples were passed through a sterile $2 \mathrm{~mm}$ sieve into a plastic zip-lock bags, which was immediately transferred into a cooling box $\left(4-10^{\circ} \mathrm{C}\right)$ containing ice. Samples were properly labelled; the cooling box was used to transfer the samples to the laboratory. Samples were then stored in the refrigerator at $4^{\circ} \mathrm{C}$ according to [24]. Then physicochemical analysis was immediately carried out on the soil samples.

\subsubsection{Determination of Soil $\mathrm{pH}$}

$\mathrm{pH}$ of soil samples was analyzed using an electronic $\mathrm{pH}$ meter, $10 \mathrm{~g}$ of the soil sample was air-dried after sieving through 2-mm mesh size and transferred into a 50ml-beaker containing $20 \mathrm{ml}$ of distilled water. The soil suspension was stirred several times for about 30 seconds using a glass rod. The suspension was allowed to stand for 2 minutes using the pH meter, Hana-digital conductivity meter model 98107 inserted into the partly settled suspension to measure the $\mathrm{pH}$, until a steady reading was obtained [18].

\subsubsection{Determination of Soil Moisture Content}

The soil moisture content was done to determine the amount of moisture in the soil sample. Four crucible covered with lid were oven dried at $105^{\circ} \mathrm{C}$ for about 2 hours. They were then cooled in a desicator and their weight was taken separately. $10 \mathrm{~g}$ of soil samples were weighed into each of the crucible and their initial weights taken. The soil samples in the crucible were transferred into oven with lid off to dry for 24 hours. Then crucible and the samples were transferred to a desiccator before weighing again until a constant weight is obtained [18]. The loss in weight was calculated, using the formula below:

$$
\text { Moisture Content }=\frac{W_{2}-W_{3}}{W_{3}-W_{1}} \times 100
$$

Where: $\mathrm{W}_{1}=$ weight of empty crucible $(\mathrm{g})$

$\mathrm{W}_{2}=$ weight of crucible + moist soil $(\mathrm{g})$

$\mathrm{W}_{3}=$ weight of crucible + oven dry soil $(\mathrm{g})$

\subsubsection{Determination of Water Holding Capacity}

Four small plastic containers with one opened end and closed end were used. A medium sized nail was used to make holes at the closed end of the containers. Whatman's no 1 filter paper that sized the perforated end was placed on the inside of the sealed end through the opened end. The filter paper was moistened with a jet of distilled water from a wash bottle. The weight of the container with the wet filter paper was recorded. Then the container was filled with oven dried soil sample of 24 hours compacted by dropping the container from a height until the soil surface was levelled. The weight was taken again and recorded. The container was put in a bowl containing water until the surface of the soil is moistened. The container was removed and put in empty Petri dish to allow the excess water to drain off. The container was then removed and weighed [18]. The quantity of moisture retained per unit weight of the oven dried soil contained in each of the container was determined using the formula below:

Mass of dry soil $=$ weight of plastic container with filter paper and soil $\left(\mathrm{W}_{2}\right)$ - weight of plastic container with filter paper $\left(\mathrm{W}_{1}\right)$

Mass of saturated soil $=$ weight of plastic container with wet soil $\left(\mathrm{W}_{3}\right)$ - weight of plastic container with filter paper $\left(\mathrm{W}_{1}\right)$

Mass of water contained in saturated soil = mass of saturated soil - mass of dry soil.

$\%$ of water holding capacity $=$ mass of water contained in the saturated soil $\mathrm{x} 100$

mass of saturated soil.

\subsubsection{Determination of Total Organic Carbon (TOC)}

Ten (10) $\mathrm{ml} 1 \mathrm{~N} \mathrm{k}_{2} \mathrm{CrO}_{7}$ was added into 5 conical flasks of $250 \mathrm{ml}, 1 \mathrm{~g}$ of each of the soil samples to be analyzed was crushed and sieved with $0.5 \mathrm{~mm}$ sieve which was transferred into each of the conical flask containing the potassium dichromate solution. $20 \mathrm{ml}$ of conc. $\mathrm{H}_{2} \mathrm{SO}_{4}$ was added into each of the conical flasks; the whole sample was then swirled gently to disperse the heat generated for 30 minutes on asbestos before cooling down. Then $100 \mathrm{ml}$ of distilled water was gradually added to each of the flask and mixed, $5 \mathrm{ml}$ of phosphoric acid was added with 3 drops of ferroin indicator to each of the samples. Titration was done using ferrous sulfate against the test samples. During titration the solution changed from a bluish-green colour upon addition of ferrous sulfate drop-wise, to a reddish grey colour or maroon colour. This was taken as the end point of the titration, the percentage carbon in the samples were calculated using the equation:

$$
\frac{(\text { Blank titre }- \text { Actual titre })}{\text { Wt of air dried soil sample }} \times 0.3 \times \mathrm{M} \times \mathrm{F}
$$


Where $\mathrm{M}=$ concentration of $\mathrm{FeS} 04$

$\mathrm{F}=$ correction factor $=1.33$

\subsection{Sterilization of Glassware and Media}

Materials which included conical flasks, funnels and test tubes were sterilized in a hot air oven at $160^{\circ} \mathrm{C}$ for about 1 hour while the media was sterilized by autoclaving at $121^{\circ} \mathrm{C}$ for 15 mins. All pipettes and other heat-resistant glassware's were wrapped in Aluminum foil to protect the items from recontamination during handling and storage before sterilization was done at $160^{\circ} \mathrm{C}$ for $1 \mathrm{hr}$ in the hot air oven. The Petri dishes used were also sterilized. Water was used to wash all the equipment's, detergents were used where necessary and $70 \%$ ethyl alcohol which is bactericidal was used to swab the top of the working bench in the laboratory where the inoculations were done.

\subsection{Microbiological Analysis and Isolation of Bacteria}

Collected soil samples transferred to the laboratory in a cooling box with ice were stored at the temperature of $4{ }^{\circ} \mathrm{C}$ until lab process and analysis takes place. Soil from each crude oil contaminated site was serially diluted using distilled water. Total heterotrophic bacteria were enumerated using the spread plate method on nutrient agar according to methods of [5]. Ten grams of each of the soil sample was weighed and transferred into $250 \mathrm{ml}$ flask containing $100 \mathrm{ml}$ of distilled water to form the neat. The solution was mixed properly and allowed to stand for 2-3 minutes after which the suspension was decanted into another $250 \mathrm{ml}$ flask. Then $1 \mathrm{ml}$ of each of the soil suspension was serially transferred into a test tube containing $9 \mathrm{ml}$ of distilled water. The suspensions were shaken intermittently for about 60 seconds. Ten-fold serial dilution was set up from the soil suspension. $0.1 \mathrm{ml}$ of the one in 104, 106 and 108 were spread in duplicate. One freshly prepared nutrient agar was poured and allowed to set. This was used as control. Plates were incubated in an inverted manner at temperature of $37^{\circ} \mathrm{C}$ for $24 \mathrm{hrs}$. Total plate counts were carried out using the colony counter. Organisms were sub-cultured in sterile nutrient agar for total heterotrophs [38]. Mineral salt agar was used for hydrocarbon utilizing organism (HUO) according to methods previously modified by Chikereet al.,[7] and also improved by American type culture collection.

\subsection{Enumeration of Hydrocarbon Utilizing Bacteria}

Culturable hydrocarbon degraders, also known as hydrocarbon utilizing bacteria (HUB) were assayed for. Here crude oil was used as the sole source of energy and carbon. Sterilized crude oil was used to soak sterilized filter paper. This was placed in the lid of inverted plates. The plates were incubated at room temperature for 6 days and HUB were counted [7]. mineral salt agar (per litre: $2.0 \mathrm{~g} \mathrm{NaNO}, 0.5 \mathrm{~g}$ $\mathrm{MgSO}_{4}, 0.5 \mathrm{~g} \mathrm{KCL}, 0.01 \mathrm{~g}, \mathrm{Fe}_{2}\left(\mathrm{SO}_{4}\right)_{3} \mathrm{H}_{2} \mathrm{O}, 0.14 \mathrm{~g} \mathrm{KH}_{2} \mathrm{PO}_{4}$, $1.2 \mathrm{~g} \mathrm{~K}_{2} \mathrm{HPO}_{4}$, $15 \mathrm{~g}$ Agar, $0.02 \mathrm{~g}$ yeast extract and $\mathrm{pH}$ 7.2) was used to culture the serially diluted samples. Plates were incubated in the dark at room temperature. $100 \mathrm{mg}$ of Nyzoral was added to make the media selective for bacteria only.

\subsubsection{Determination of Bacterial Growth Curve}

Optical densities readings were taken by taking a loopful of the bacterial growth on mineral salt agar into a test tube containing saline, by adjusting the turbidity of the bacterial suspension to match with the turbidity of $0.5 \%$ McFarland which is approximately $1 \times 10^{8} \mathrm{CFU} / \mathrm{ml}$. The $0.5 \%$ of McFarland solution was prepared by mixing $0.5 \mathrm{ml}$ of $1.175 \%$ barium chloride dehydrate, with $99.5 \mathrm{ml}$ of $1 \%$ sulfuric acid. Readings were taken for a period of 5 days. The optical density was measured at $600 \mathrm{~nm}$ using the Spectrophotometer.

\subsubsection{Determination of Bacterial Adaptation Using Strain Improvement Test}

Bacterial isolates which showed optimal growth curve were further subjected to growth adaptation, using mineral salt broth containing $1 \mathrm{ml}$ and $2 \mathrm{ml}$ of sterile crude oil in a test tube covered with sterile cotton plug, incubation was done at $37^{\circ} \mathrm{C}$ in an incubator for a period of 5 days. Optical density and $\mathrm{pH}$ of the bacterial broth was measured with a $\mathrm{pH}$ meter and spectrophotometer at everyday interval throughout the period of 5 days [6].

\subsection{Characterization and Biochemical Identification of Isolates}

Pure isolates were examined for their cultural appearance. Endospore and Grams staining techniques were performed to establish the cell morphology of the isolates. motility, citrate utilization, oxidase, triple sugar iron test, catalase and indole tests were carried out according to methods of Umeaku[39] and Cheesbrough[5] Microbial identification was performed using the keys provided by Bergey's Manual of Determinative Bacteriology (1994).

\subsection{Biodegradation Studies}

The biodegradation of the crude oil was carried out in the laboratory using liquid medium. Method of Ekpo and Ekpo[10] was adopted, 1 litre of mineral salt broth was prepared and autoclaved, $99 \mathrm{ml}$ of the liquid medium was dispensed each into four different sterile $250 \mathrm{ml}$ amber bottle then $1 \mathrm{ml}$ of sterile crude oil was added into each of the amber bottles, and inoculated with five millilitre of improved bacterial strain, one was left uninoculated, it served as the control. The bottles were then incubated at an ambient temperature $\left(30^{\circ} \mathrm{C}\right)$ in a dark cupboard for 14 days, with manual shaking of 100 strokes per minute for 30 minutes, each day for 14 days. Bacterial growth rate and $\mathrm{pH}$ were determined for the initial day and every 7 days [10]. The total petroleum hydrocarbon was monitored and measured for changes using gas chromatography [30].

\subsection{Gas Chromatographic Analysis}

Total petroleum hydrocarbon analysis was done using the four samples from the biodegradation studies. Before the biodegradation studies isolates which showed ability to 
grow and use the crude oil present in mineral salt agar using vapour phase method were transferred to the mineral salt broth for optimal growth and adaptability. The residual total petroleum hydrocarbons (TPHs) were extracted from the mineral salt broth containing organisms isolated from different soil samples collected from Anambra, Abia and River state. Quantification was done using gas chromatograph-flame ionization detector (GC- FID) at seven days' interval for 14 days according to the methods of ASTM D3912(2013) and USEPA (2007). At Anal Concept Laboratory Port-Harcourt. A $250 \mathrm{ml}$ of liquid sample was measured out into a separating funnel, the container was rinsed with dichloromethane then $25 \mathrm{ml}$ of dichloromethane was added to the $250 \mathrm{ml}$ of liquid sample. The separating funnel was then mixed vigorously to allow homogenization of the organic solvents. The organic extract was collected into a receiving container, and then the organic extract was passed through a column containing cotton plug silica gel and anhydrous sodium sulphate. The collected organic extract about $(1 \mu \mathrm{l})$ was injected into the gas chromatograph machine model 5890 series II (using a micro syringe) through a rubber septum into a flash vaporizing port at the head of the column. The temperature of the sample port is about $60^{\circ} \mathrm{C}$ higher than the boiling point of the least volatile component of the sample. Inside the GC the carrier gas (hydrogen) was allowed to move each analyte through a capillary column with the length and temperature of $30 \mathrm{~m}$ and $278^{\circ} \mathrm{C}$. Each analyte required a different amount of time to pass through the column. The sample's outlet stream was monitored using a flame ionization detector; results of different hydrocarbon were shown in chromatograms [38].

\subsection{Molecular Analysis}

DNA extraction and purification - Zymo research kit was used.

DNA quantity and quality analysis by nanodrop spectrophotometer.

DNA Amplification - Eppendorf thermocycler was used.

Gel electrophoresis of DNA and PCR products.

PCR products purification and DNA sequencing of $16 \mathrm{~s}$ rDNA gene.

\subsubsection{DNA Extraction and Purification - Zymo Research Kit Was Used}

The DNA extraction and purification was carried out by adding 100mg (wet weight) of bacterial cells into a bashing tube containing $200 \mu \mathrm{l}$ of isotonic buffer, then $750 \mu \mathrm{l}$ of lysis solution was added to the tube. Tube was then secured in a bead fitted with $2 \mathrm{ml}$ tube holder assembly and process at maximum speed for $>5$ minutes, centrifugation of the ZR bashing bead TM lysis tube was carried out in a microcentrifuge at $>10,000 \mathrm{x} \mathrm{g}$ for 1 minute. Then $400 \mu \mathrm{l}$ supernatant was transferred to a Zymo-spinTM IV spin filter (orange top) in a collection tube and centrifuged at 7,000 $\mathrm{xg}$ for 1 minute., prior to this the base of the Zymo-spin TM spin filter was snapped off. After that, 1,200 $\mu$ l of bacterial DNA binding buffer was added to the filtrate in the collection tube and $800 \mu \mathrm{l}$ of the mixture was transferred to a Zymo-spinTM IIC column in a collection tube and centrifuged at 10,000 $\mathrm{xg}$ for 1 minute. This step was repeated twice because the Zymo-spinTM IIC column has a maximum capacity of 800 $\mu 1$. the flow through from the collection tube was discarded, $200 \mu 1$ DNA pre-wash buffer was added to the Zymo-spin TM IIC column in new collection tube and centrifugation was done at $10,000 \mathrm{x} \mathrm{g}$ for 1 minute and $500 \mu \mathrm{l}$ bacterial DNA wash buffer was also added to the Zymo-spinTM IIC column and it was also centrifuged at $10,000 \times \mathrm{g}$ for 1 minute. The Zymo-spinTM IIC column was then transferred to a clean $1.5 \mathrm{ml}$ micro-centrifuge tube and 100ulDNA elution bufferwas added directly to the column matrix before centrifuging at $10,000 \mathrm{x}$ g for 30 seconds to elude the DNA. DNA was now suitable for PCR.

\subsubsection{Preparation of Agarose Electrophoresis}

Agarose gel electrophoresis was prepared by weighing out the appropriate amount of $1.5 \mathrm{~g}$ of agarose into a $100 \mathrm{ml}$ of tris borate EDTA from a 10x TBE into a $250 \mathrm{ml}$ flask. This was melted in the microwave oven for 1 minute and 20 seconds, the solution was visually checked to see that all the agarose has melted. Unmelted agarose which looked like tiny refractive lenses floating around was heated a little longer. Then the electrophoretic tank was set up. The agarose was brought out of the oven and allowed to cool to $55^{\circ} \mathrm{C}, 5 \mu \mathrm{l}$ of GR green was then added after cooling the gel. The TBE/Gel was poured onto the gel tray; pouring was done up to half the height of the teeth of the comb inserted on the gel tray. Bubbles were chased out on the surface with a plastic micropipette tip. The gel was allowed to cool until it turns slightly white; this usually takes at least 20 minutes at room temperature, the comb was removed, and enough $1 \mathrm{X}$ TAE was poured into the buffer chamber to cover the top surface of the gel, then $10 \mathrm{ml}$ of each of the extracted DNA was mixed with $5 \mathrm{ml}$ of GR green, micropipette was used to load $2.0 \mu 1$ of the DNA mixture onto the wells on gel tray of the electrophoretic tank. The gel wells were positioned at the cathode end of the gel electrophoretic tank, each of the light sources was then plugged in with electric current switched on at 100 volts which run for about 1hour, and then the separated gel was viewed at the documentation chamber under an ultra violet light.

\subsubsection{DNA Quantity and Quality Analysis by Nanodrop2000 Spectrophotometer}

The upper and lower optical surfaces of the micro volume spectrophotometer sample retention system was cleaned, by pipetting 2-3 $\mu 1$ of clean deionized water unto the lower optical surface. The lever arm was then closed to ensure that the upper pedestal comes in contact with the deionized water before lifting the lever arm and wiping off both optical surfaces with a clean dry free lab wipe. The nano-drop software was then opened to select the nucleic acid application, after which a small volume calibrated pipette was used to perform a blank measurement by dispensing $1 \mu \mathrm{l}$ of buffer unto the lower optical surface then the lever arm was lowered to carry out a 
blank measurement. Once the blank measurement was completed, cleaning of both optical surfaces with a laboratory wipe was done as before. Then $1 \mu$ l of nucleic acid sample was transferred unto the lower optical pedestal and lever arm was closed, this was followed by selecting the measure icon in the application software, this software then automatically calculates the nucleic acid concentration and purity ratio following sample measurement.

\subsubsection{DNA Amplification - Eppendorf Thermocycler Was Used}

PCR reaction carried out by placing the required components in a tube on ice, the components added were; $10 \times$ PCR buffer $2.5 \mu 1, \mathrm{mgcl} 21.0 \mu 1,5 \mathrm{pmol}$ forward primer $1.0 \mu 1$, 5pmol reverse primer $1.0 \mu 1$, DMSO $1.0 \mu 1$, DNTPs $2.0 \mu 1$, taq polymerase $0.1 \mu 1$, DNA $3.0 \mu 1$, H2O $13.4 \mu 1$. The six DNA samples for amplification was then transferred to Eppendorf thermocycler for DNA amplification with a preprogrammed temperature cycle of $94^{\circ} \mathrm{C}$ to denature the DNA double strands, $56^{\circ} \mathrm{C}$ to enable the forward and reverse primer to anneal to the DNA single strands, and a final temperature of $72{ }^{\circ} \mathrm{C}$ to allow for the extension of the individual DNA strands, a total number of 36 circles was carried out. The amplicon from the reaction was loaded on $1.5 \%$ agarose gel and the gel picture is called PCR product. The ladder used is $1 \mathrm{~kb}$ plus ladder from Invitrogen. The expected base pair of the amplicon is around $1500 \mathrm{bp}$.

\subsubsection{PCR Products Purification and DNA Sequencing of 16s Rdnagene}

This was forwarded outside Nigeria.

\subsection{Statistical Analysis}

The major statistical technique used in this study for the analysis of the collected data is Analysis of Variance (ANOVA). In this study, only one-way was used to present the data.

\section{Results}

\subsection{Crude Oil Contaminated Soil}

The physico-chemical analysis of the contaminated soil sample showing the percentage of total organic matter, $\mathrm{pH}$, moisture content, water holding capacity of the crude oil soil samples are presented in Table 1: below.

Table 1. Physico-chemical analysis/properties of the soil.

\begin{tabular}{lllll}
\hline Sample & pH & $\begin{array}{l}\text { moisture } \\
\text { content (\%) }\end{array}$ & $\begin{array}{l}\text { water holding } \\
\text { capacity (\%) }\end{array}$ & $\begin{array}{l}\text { TOC } \\
(\%)\end{array}$ \\
\hline A & 3.7 & 3.0 & 28.7 & 3.4 \\
B & 5.9 & 1.6 & 22.4 & 4.6 \\
C & 6.6 & 2.0 & 32.0 & 3.6 \\
D & 6.1 & 4.4 & 28.0 & 7.1 \\
\hline
\end{tabular}

TOC:Total organic carbon

A:soil sample from Abia State.

B:soil sample from Anambra State.

C:soil sample from River State.

D:Uncontaminated soil.

\subsection{Isolation and Enumeration of Bacteria}

The results of the total heterotrophic bacteria (THB) using plate count and hydrocarbon utilizing bacteria (HUB) using spectrophotometer were presented in Table 2: and Table 3: respectively. Results shows that the population of total heterotrophic bacteria (THB).

Table 2. Microbial counts of the total heterotrophs in CFU/ml.

\begin{tabular}{llll}
\hline Sample & dilution factor & No of colonies & Cfu/ml \\
\hline A1 & $10^{4}$ & 82 & $8.2 \times 10^{6}$ \\
A2 & $10^{6}$ & 48 & $4.8 \times 10^{8}$ \\
A3 & $10^{8}$ & 33 & $3.3 \times 10^{10}$ \\
B1 & $10^{4}$ & 71 & $7.1 \times 10^{6}$ \\
B2 & $10^{6}$ & 54 & $5.4 \times 10^{8}$ \\
B3 & $10^{8}$ & 39 & $3.9 \times 10^{10}$ \\
C1 & $10^{4}$ & 124 & $1.24 \times 10^{7}$ \\
C2 & $10^{6}$ & 96 & $9.6 \times 10^{8}$ \\
C3 & $10^{8}$ & 59 & $5.9 \times 10^{10}$ \\
D1 & $10^{4}$ & 87 & $8.7 \times 10^{6}$ \\
D2 & $10^{6}$ & 70 & $7.0 \times 10^{8}$ \\
D3 & $10^{8}$ & 35 & $3.5 \times 10^{10}$ \\
Control & No growth & & \\
\hline
\end{tabular}

\subsection{Determination of Bacterial Growth Population}

Optical density of $600 \mathrm{~nm}$ was used to determine the growth population of bacterial isolate during vapour-phase method on mineral salt agar.

Table 3. Optical density measurement at 600nm.

\begin{tabular}{llllll}
\hline Sample & $\mathbf{1}^{\text {st }} \mathbf{d a y}$ & $\mathbf{2}^{\text {nd }} \mathbf{d a y}$ & $\mathbf{3}^{\text {rd }} \mathbf{d a y}$ & $\mathbf{4}^{\text {th }} \mathbf{d a y}$ & $\mathbf{5}^{\text {th }} \mathbf{d a y}$ \\
\hline A1 & 0.173 & 0.286 & 0.312 & 0.442 & 0.585 \\
A2 & 0.168 & 0.274 & 0.288 & 0.394 & 0.318 \\
A3 & 0.182 & 0.322 & 0.484 & 0.512 & 0.664 \\
B1 & 0.177 & 0.280 & 0.281 & 0.282 & 0.311 \\
B2 & 0.166 & 0.268 & 0.277 & 0.380 & 0.415 \\
B3 & 0.175 & 0.282 & 0.289 & 0.398 & 0.467 \\
C1 & 0.188 & 0.394 & 0.400 & 0.411 & 0.540 \\
C2 & 0.180 & 0.382 & 0.494 & 0.598 & 0.614 \\
C3 & 0.164 & 0.265 & 0.265 & 0.270 & 0.373 \\
D1 & 0.168 & 0.269 & 0.270 & 0.374 & 0.375 \\
D2 & 0.166 & 0.267 & 0.268 & 0.268 & 0.369 \\
D3 & 0.167 & 0.267 & 0.268 & 0.369 & 0.370 \\
Control & 0.065 & 0.064 & 0.069 & 0.068 & 0.068 \\
Standard & 0.122 & 0.122 & 0.121 & 0.121 & 0.122 \\
\hline
\end{tabular}

Table 4. Strain improvement test at 600nm.

\begin{tabular}{lllllll}
\hline Sample & $\begin{array}{l}\text { \% of } \\
\text { crude oil }\end{array}$ & $\mathbf{1}^{\text {st }}$ day & $\mathbf{2}^{\text {nd }} \mathbf{d a y}$ & $\mathbf{3}^{\text {rd }} \mathbf{d a y}$ & $\mathbf{4}^{\text {th }} \mathbf{d a y}$ & $\mathbf{5}^{\text {th }}$ day \\
\hline A1 & $1 \mathrm{ml}$ & 0.114 & 0.287 & 0.418 & 0.426 & 0.522 \\
$\mathrm{~A} 1$ & $2 \mathrm{ml}$ & 0.124 & 0.246 & 0.318 & 0.324 & 0.428 \\
$\mathrm{~A} 2$ & $1 \mathrm{ml}$ & 0.116 & 0.218 & 0.223 & 0.326 & 0.429 \\
$\mathrm{~A} 2$ & $2 \mathrm{ml}$ & 0.126 & 0.220 & 0.224 & 0.328 & 0.332 \\
$\mathrm{~A} 3$ & $1 \mathrm{ml}$ & 0.112 & 0.212 & 0.321 & 0.423 & 0.543 \\
$\mathrm{~A} 3$ & $2 \mathrm{ml}$ & 0.101 & 0.232 & 0.314 & 0.412 & 0.412 \\
$\mathrm{~B} 1$ & $1 \mathrm{ml}$ & 0.112 & 0.114 & 0.245 & 0.248 & 0.255 \\
$\mathrm{~B} 1$ & $2 \mathrm{ml}$ & 0.112 & 0.113 & 0.113 & 0.214 & 0.244 \\
$\mathrm{~B} 2$ & $1 \mathrm{ml}$ & 0.113 & 0.217 & 0.224 & 0.328 & 0.336 \\
$\mathrm{~B} 2$ & $2 \mathrm{ml}$ & 0.115 & 0.120 & 0.220 & 0.225 & 0.330 \\
B3 & $1 \mathrm{ml}$ & 0.112 & 0.216 & 0.318 & 0.419 & 0.520 \\
\hline
\end{tabular}




\begin{tabular}{lllllll}
\hline Sample & $\begin{array}{l}\text { \%o of } \\
\text { crude oil }\end{array}$ & $\mathbf{1}^{\text {st }}$ day & $\mathbf{2}^{\text {nd }} \mathbf{d a y}$ & $\mathbf{3}^{\text {rd }} \mathbf{d a y}$ & $\mathbf{4}^{\text {th }}$ day & $\mathbf{5}^{\text {th }}$ day \\
\hline B3 & $2 \mathrm{ml}$ & 0.110 & 0.212 & 0.227 & 0.317 & 0.418 \\
C1 & $1 \mathrm{ml}$ & 0.115 & 0.220 & 0.225 & 0.329 & 0.438 \\
C1 & $2 \mathrm{ml}$ & 0.114 & 0.221 & 0.232 & 0.326 & 0.332 \\
C2 & $1 \mathrm{ml}$ & 0.116 & 0.240 & 0.242 & 0.324 & 0.324 \\
C2 & $2 \mathrm{ml}$ & 0.113 & 0.118 & 0.219 & 0.220 & 0.322 \\
C3 & $1 \mathrm{ml}$ & 0.112 & 0.114 & 0.142 & 0.262 & 0.313 \\
C3 & $2 \mathrm{ml}$ & 0.110 & 0.110 & 0.110 & 0.221 & 0.241 \\
Control & 0.010 & 0.109 & 0.203 & 0.205 & 0.212 & \\
\hline
\end{tabular}

Table 5. Absorbance and $\mathrm{pH}$ value using spectrophotometer (600nm) showing growth of isolates during biodegradation.

\begin{tabular}{llll}
\hline Isolate & Day 1 & Day 7 & Day 14 \\
\hline Hub-A1, A3 & 0.128 & 0.236 & 0.445 \\
pH & 7.22 & 7.43 & 7.96 \\
Hub-B2, B3 & 0.127 & 0.330 & 0.538 \\
pH & 7.31 & 7.39 & 7.44 \\
Hub-C1, C2 & 0.130 & 0.239 & 0.594 \\
pH & 7.32 & 7.38 & 7.46 \\
Control & 0.118 & 0.119 & 0.122 \\
pH & 7.23 & 7.20 & 7.12 \\
\hline
\end{tabular}

Table 6. Biochemical characterization of isolates.

\begin{tabular}{llllllll}
\hline Isolate & $\begin{array}{l}\text { Morphological } \\
\text { Characteristics }\end{array}$ & Gram stain & Spore stain & Catalase & Oxidase & indole & Citrate \\
\hline A1 & Rod & + & + & + & - & - & + \\
A2 & Rod & - & - & + & + & - & + \\
A3 & Rod & - & - & + & - & - & + \\
B1 & Cocci & + & + & + & + & - & + \\
B2 & Rod & + & + & + & + & + & + \\
B3 & Rod & + & - & + & + & - & + \\
C1 & Rod & - & + & + & + & - & + \\
C2 & Rod & + & + & + & + & - & + \\
C3 & Rod & + & + & + & - & - & + \\
D1 & Rod & + & + & + & - & + \\
D2 & Rod & + & - & + & + & + \\
D3 & Rod & - & - & + & + & + \\
\hline
\end{tabular}

Table 6. Continued.

\begin{tabular}{|c|c|c|c|c|c|c|c|}
\hline Isolate & $\mathrm{H}_{2} \mathrm{~S}$ & Motility & Glucose & Lactose & Gas prod & TSI & Organism \\
\hline A1 & - & + & - & - & - & $\mathrm{K} / \mathrm{NC}$ & Bacillus spp. \\
\hline A2 & - & + & - & - & - & $\mathrm{K} / \mathrm{NC}$ & Pseudomonas spp. \\
\hline A3 & + & + & + & - & + & $\mathrm{A} / \mathrm{A}$ & Serratia spp. \\
\hline B1 & - & + & + & - & - & $\mathrm{A} / \mathrm{A}$ & Micrococcus spp. \\
\hline B2 & + & - & + & + & + & $\mathrm{A} / \mathrm{A}$ & Bacillus spp. \\
\hline B3 & + & - & + & + & + & $\mathrm{A} / \mathrm{A}$ & Bacillusspp. \\
\hline $\mathrm{C} 1$ & + & + & + & + & + & $\mathrm{A} / \mathrm{A}$ & Proteus spp. \\
\hline $\mathrm{C} 2$ & + & - & + & - & - & $\mathrm{K} / \mathrm{A}$ & Bacillus spp. \\
\hline $\mathrm{C} 3$ & + & - & + & + & + & $\mathrm{A} / \mathrm{A}$ & Arthrobacter spp. \\
\hline D1 & - & + & + & - & - & $\mathrm{K} / \mathrm{A}$ & Bacillus spp. \\
\hline D2 & + & + & + & + & + & $\mathrm{A} / \mathrm{A}$ & Arthrobacter spp. \\
\hline D3 & - & - & + & - & - & $\mathrm{K} / \mathrm{A}$ & Shigella spp. \\
\hline
\end{tabular}

keys: $+=$ positive,$-=$ negative,

$\mathrm{K} / \mathrm{A}=$ only glucose fermented., $\mathrm{A} / \mathrm{A}=$ glucose and lactose $/$ sucrose fermented.

$\mathrm{K} / \mathrm{NC}=$ no sugar fermented.

Table 7. TPH concentration of the mineral salt medium with the organisms analyzed.

\begin{tabular}{llll}
\hline Sample & Day $\mathbf{0}(\mathbf{m g} / \mathbf{k g})$ & Day $\mathbf{7}(\mathbf{m g} / \mathbf{k g})$ & Day $\mathbf{1 4}(\mathbf{m g} / \mathbf{k g})$ \\
\hline A & 582.668 & 454.543 & 123.666 \\
B & 682.647 & 531.891 & 203.846 \\
C & 753.320 & 411.577 & 324.769 \\
D & 812.325 & 792.345 & 781.338 \\
\hline
\end{tabular}

TPH: Total petroleum hydrocarbon

A:Abia state

B:Anambra state

C:River state

D:Control 
Table 8. Reaction mixture and volume pipetted.

\begin{tabular}{ll}
\hline PCR Mixtures & Volume $(\mu \mathbf{L})$ \\
\hline $10 \times$ PCR buffer & 2.5 \\
$25 \mathrm{mM} \mathrm{Mgcl} 2$ & 1.0 \\
$5 \mathrm{pMol}$ forward primer & 1.0 \\
$5 \mathrm{pMol}$ reverse primer & 1.0 \\
DMSO & 1.0 \\
$2.5 \mathrm{mM}$ DNTPs & 2.0 \\
Taq 5u/ul & 0.1 \\
$10 \mathrm{ng} / \mu 1$ DNA & 3.0 \\
H2O & 13.4 \\
Total/Rxn Volume & $25 \mu \mathrm{L}$ \\
\hline
\end{tabular}

Table 9. Steps involved in the polymerase chain reaction.

\begin{tabular}{lllllll}
\hline Initial den. & Den. & Ann. tempt & Extension & No. of circles & Final extension & Hold tempt \\
\hline $94^{\circ} \mathrm{c}$ & $94^{\circ} \mathrm{c}$ & $56^{\circ} \mathrm{c}$ & $72^{\circ} \mathrm{c}$ & 36 & $72^{\circ} \mathrm{c}$ & $10^{\circ} \mathrm{c}$ \\
$5 \mathrm{~min}$ & $30 \mathrm{sec}$ & $30 \mathrm{sec}$ & $45 \mathrm{sec}$ & & $7 \mathrm{~min}$ & $\infty$ \\
\hline
\end{tabular}

Table 10. DNA Quantification of the six samples with Nanodrop-2000 spectrophotometer.

\begin{tabular}{lll}
\hline Sample ID & Nucleic Acid $(\boldsymbol{\mu g} / \boldsymbol{\mu l})$ & $\mathbf{2 6 0 / 2 8 0}(\mathbf{q u a l i t y})$ \\
\hline sample 1 & 80.1 & 1.81 \\
sample 2 & 161.6 & 1.8 \\
sample 3 & 149.2 & 1.85 \\
sample 4 & 152 & 1.85 \\
sample 5 & 125.7 & 1.86 \\
sample 6 & 145.8 & 1.84 \\
\hline
\end{tabular}

Table 11. Result and Inferences from the molecular characterization and identification sequences.

\begin{tabular}{|c|c|c|c|c|c|c|c|}
\hline Isolate & Max Score & Total Score & Query Cover & E. value & Identity & Accession number & Description \\
\hline A1 & 924 bits & 924 & $100 \%$ & 0.0 & $100 \%$ & KY705015.1 & LysinibacillussppM2c. \\
\hline A3 & 1286 bits & 700 & $100 \%$ & 0.0 & $99 \%$ & D10387 & Serratia spp Mb4. \\
\hline B2 & 1437 bits & 1437 & $100 \%$ & 0.0 & $100 \%$ & KX834865.1 & Bacillus aerius TPM-23 \\
\hline B3 & 582 bits & 582 & $100 \%$ & $2 \mathrm{e}-16^{2}$ & $95 \%$ & KY777602.1 & Unknown isolate \\
\hline $\mathrm{C} 1$ & 998 bits & 540 & $100 \%$ & 0.0 & $100 \%$ & KX417275 & Proteus mirabilis LS-3 \\
\hline $\mathrm{C} 2$ & 237 bits & 237 & $67 \%$ & $2 \mathrm{e}-58$ & $79 \%$ & EF153309.1 & New isolate \\
\hline
\end{tabular}

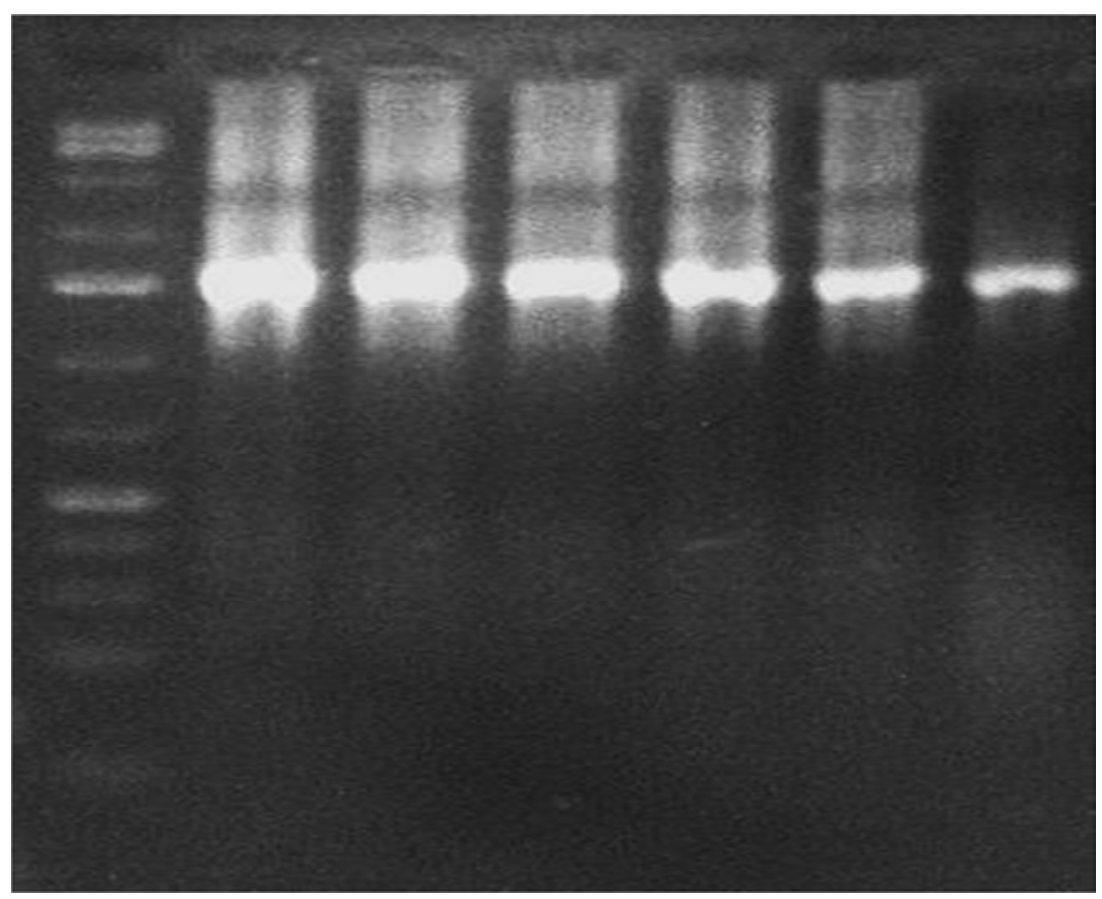

Figure 1. Gel electrophoresis showing PCR product for the 6 samples on 1.5\%Agarose gel where L = Ladder, samples 1-6, showing; Lysinibacillus spp. M2c, Serratiamarcescens Mb4., Bacillus aeriusTPM-23, Unknown isolate, Proteus mirabilis LS-3, a new isolate. 
TPH concentration Day 0 (Abia).

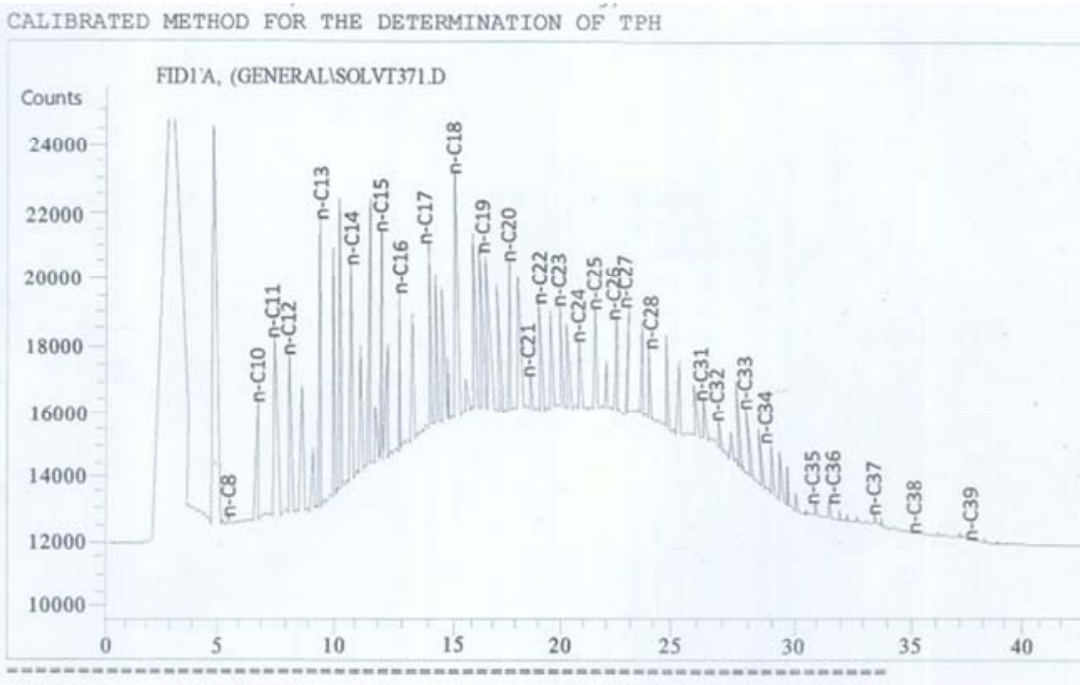

Figure 2. TPH concentration Day 7 (Abia).

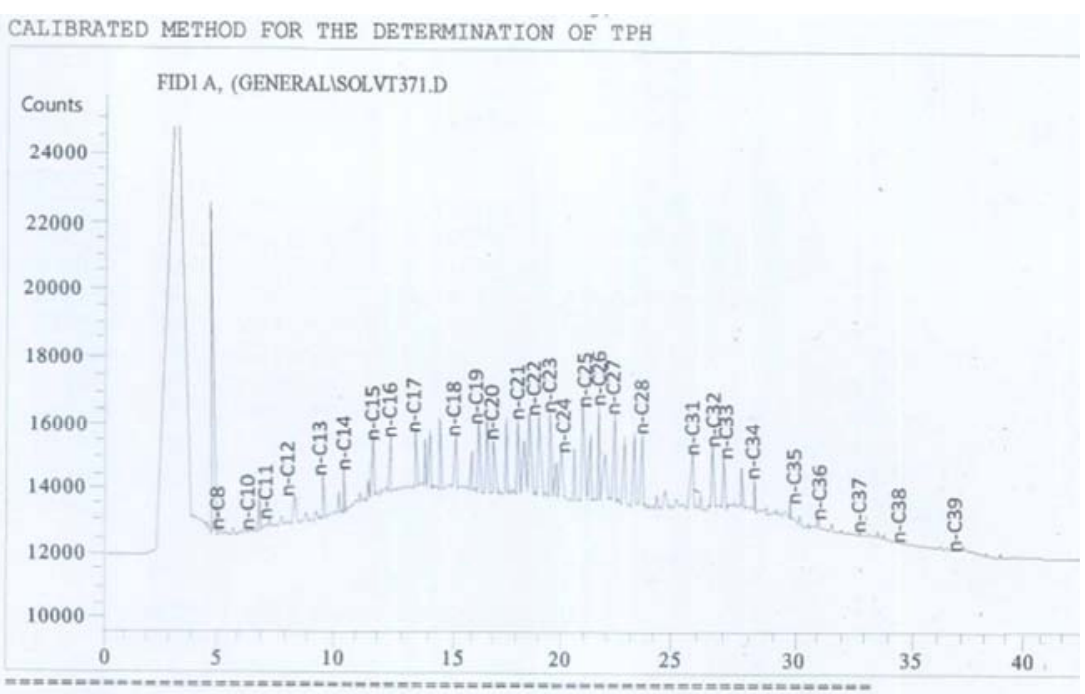

Figure 3. TPH concentration Day 14 (Abia).

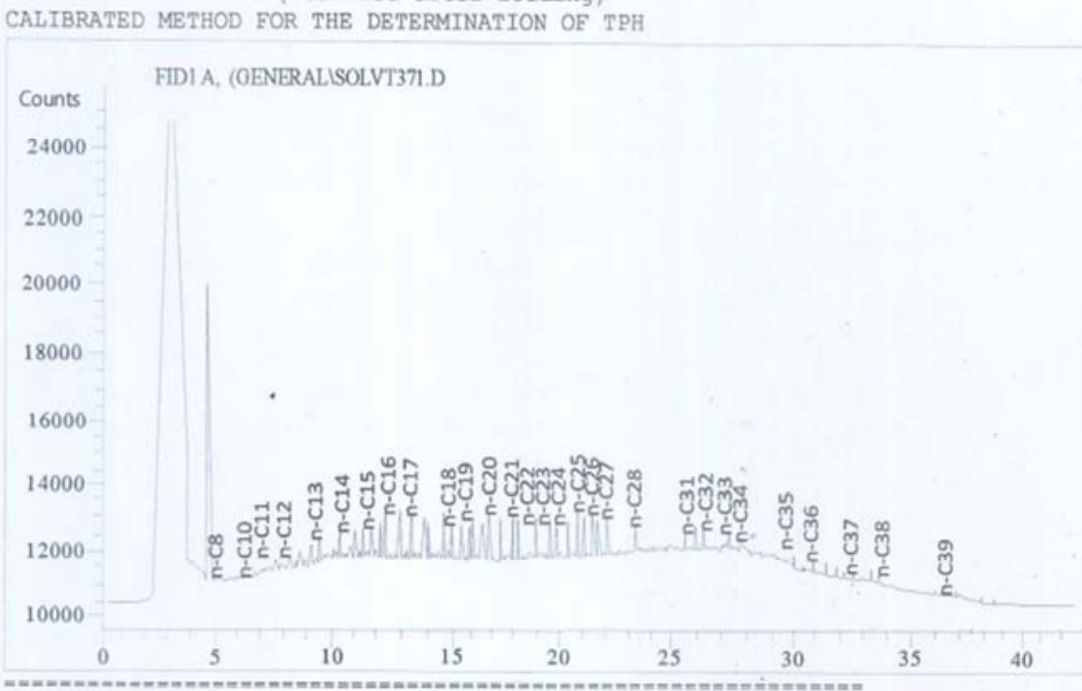

Figure 4. TPH concentration Day O(Anambra). 


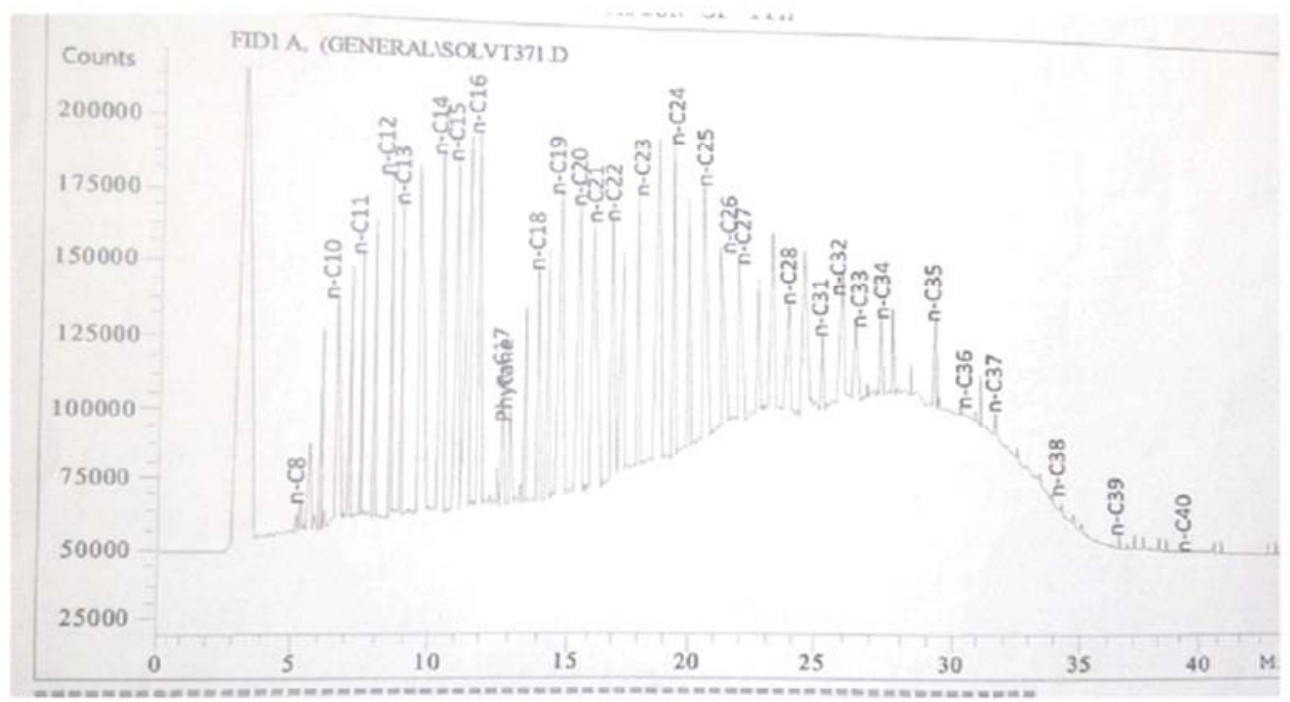

Figure 5. TPH concentration Day 7 (Anambra).

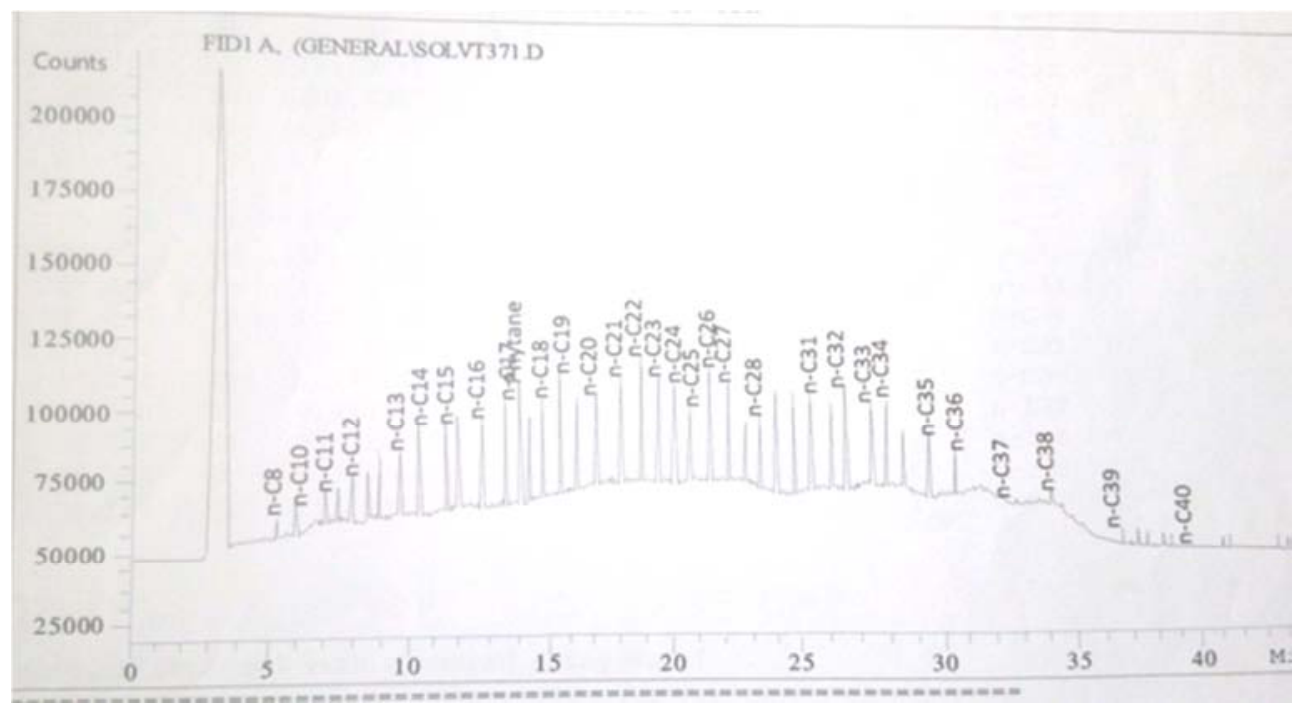

Figure 6. TPH concentration Day 14 (Anambra).

ZALIBRATED METHOD FOR THE DETERMINATION OF TPH

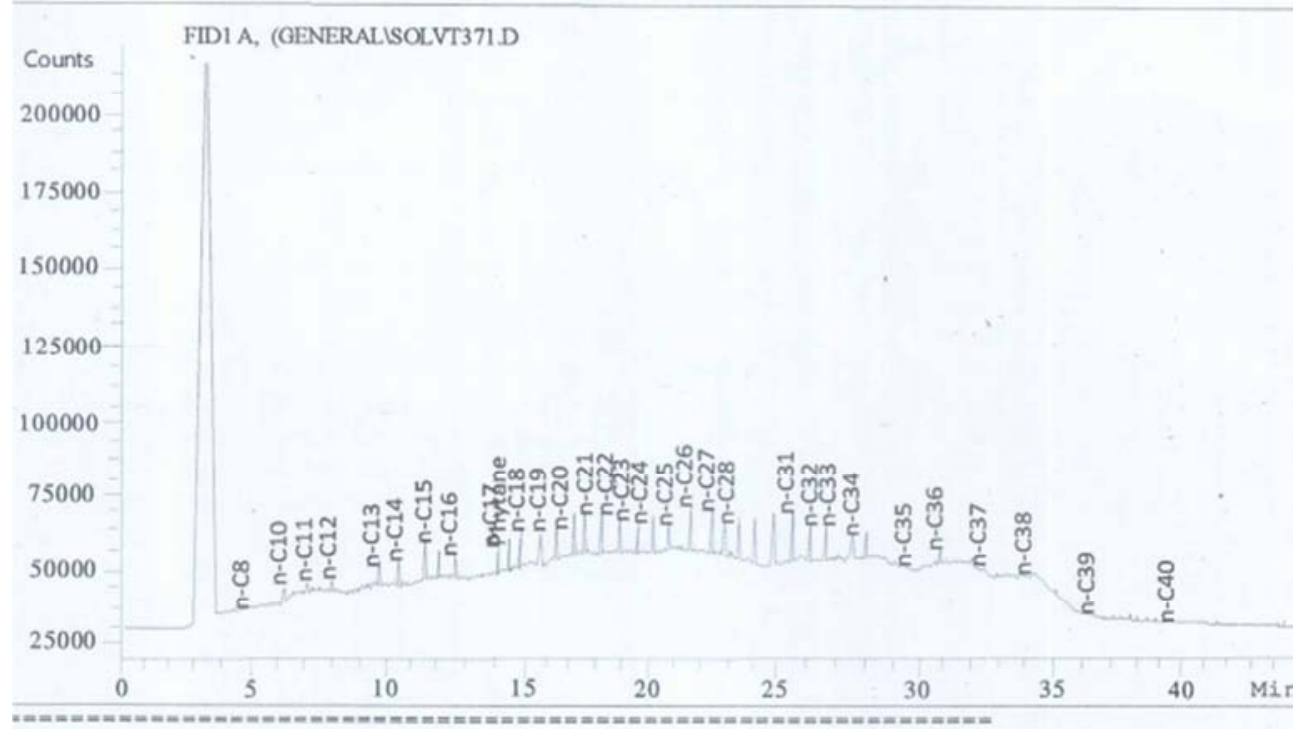

Figure 7. TPH concentration Day 0 (Rivers). 


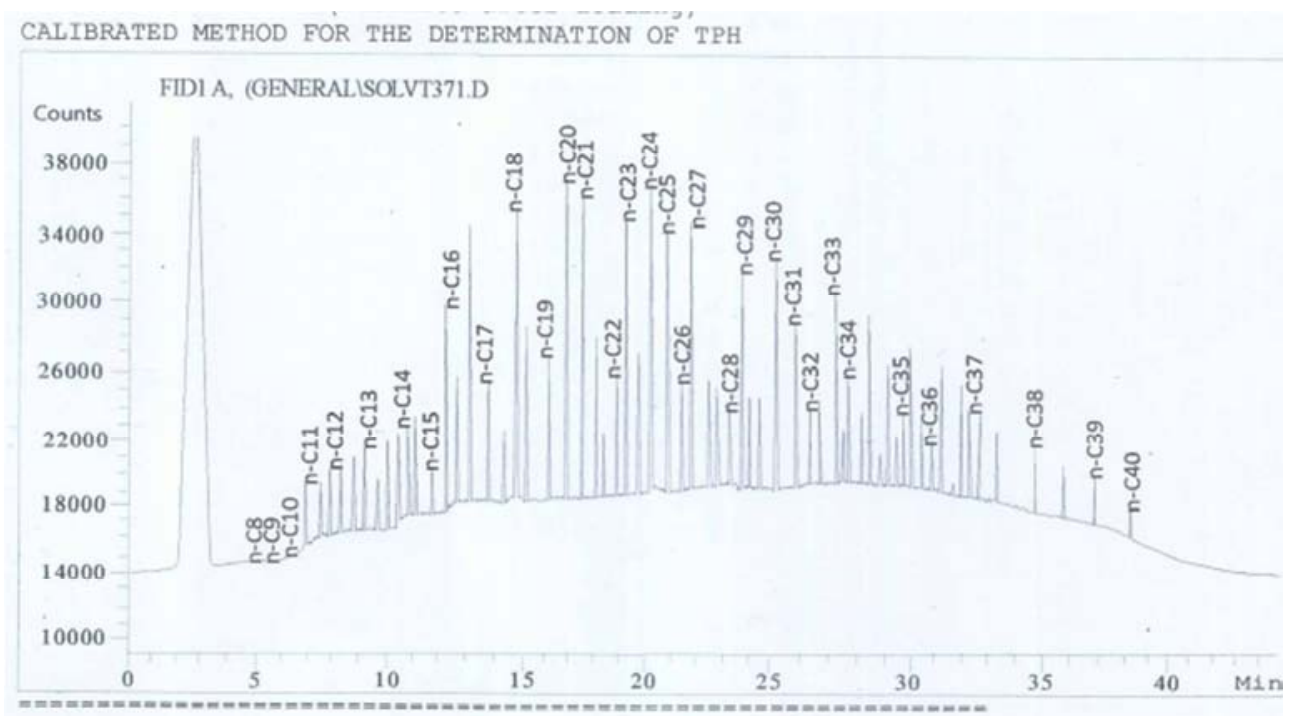

Figure 8. TPH concentration Day 7 (Rivers).

CALIBRATED METHOD FOR THE DETERMINATION OF TPH

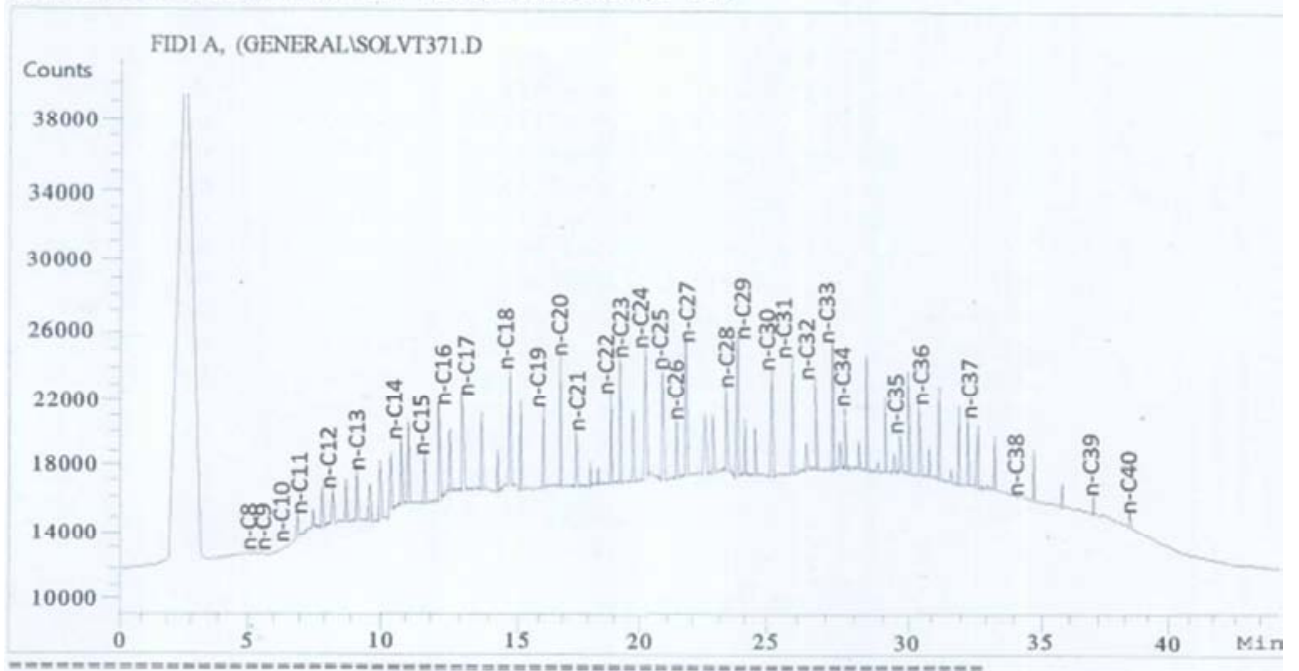

Figure 9. TPH concentration Day 14 (Rivers).

CALIBRATED METHOD FOR THE DETERMINATION OF TPH

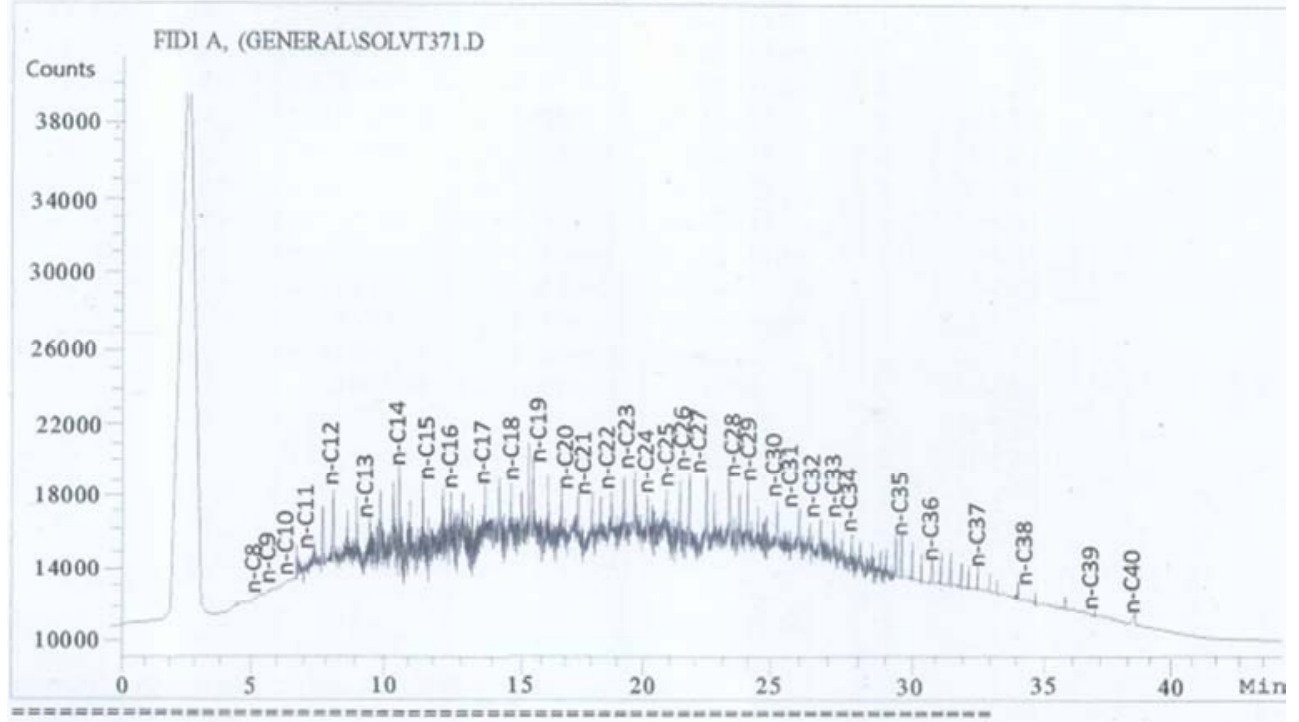

Figure 10. TPH concentration Day 0 (control). 


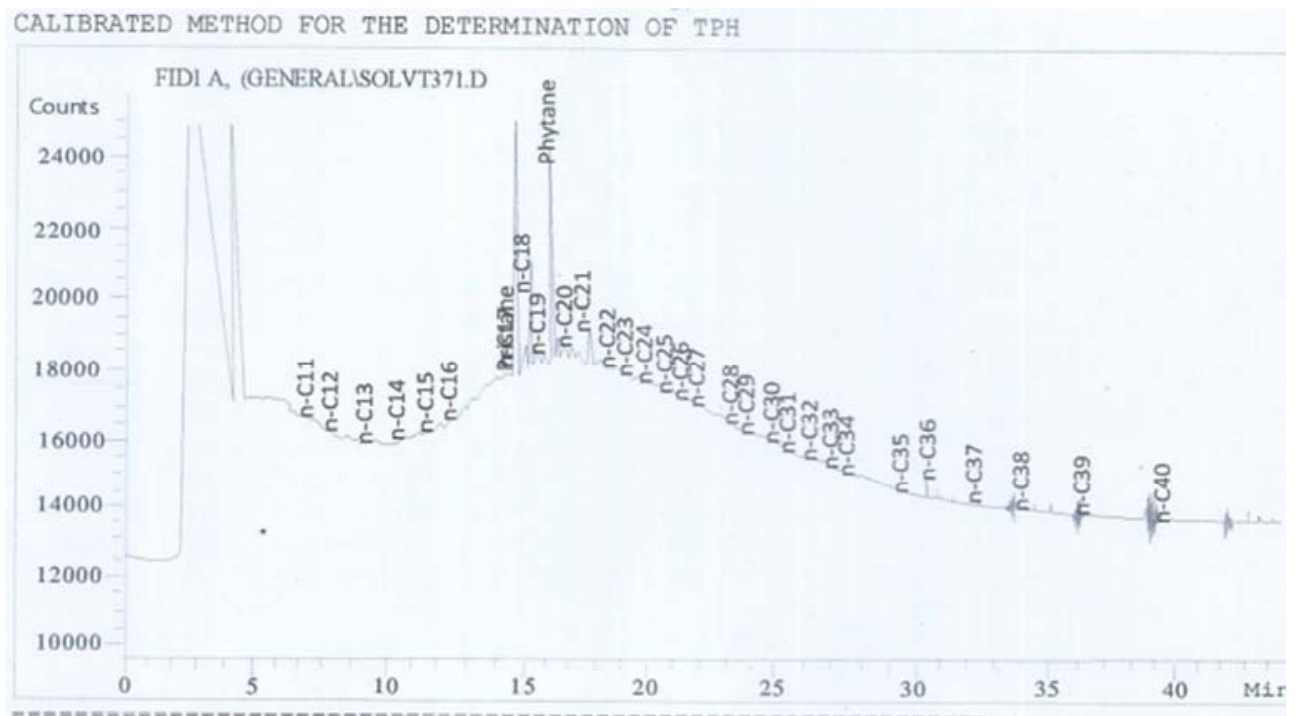

Figure 11. TPH concentration Day 7 (control).

CALIBRATED METHOD FOR THE DETERMINATION OF TPH

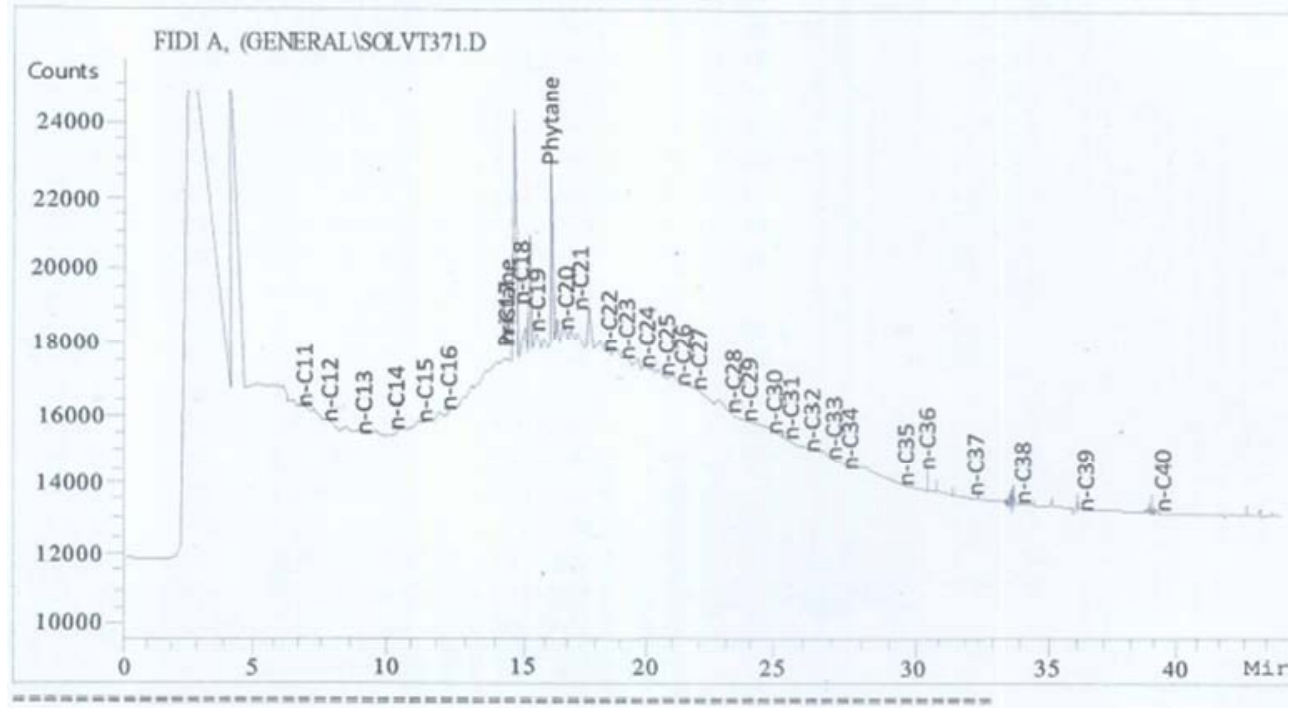

Figure 12. TPH concentration Day 14 (control).

CALIBRATED METHOD FOR THE DETERMINATION OF" TPH

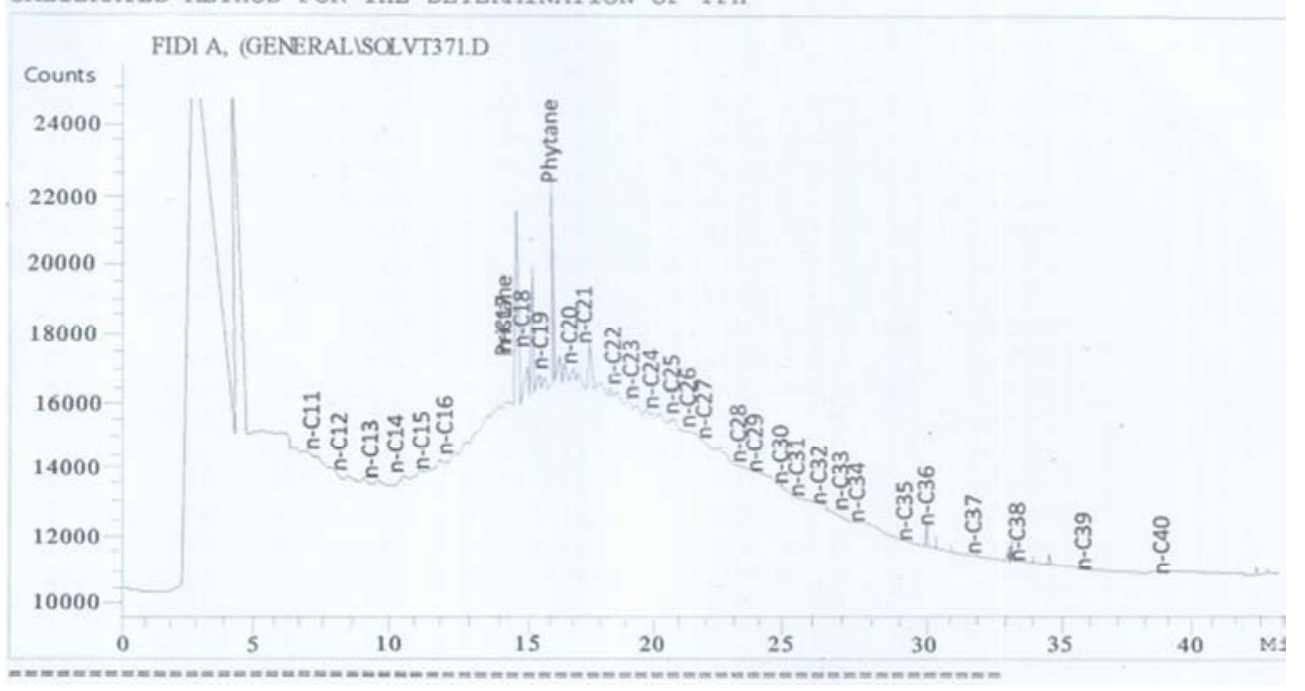

Figure 13. TPH concentration Day 21. 


\subsection{Statistical Analysis}

In testing for the significance of the growth of the microorganisms, bacteria, a One-Way ANOVA was conducted. This One-way ANOVA was conducted to test for the difference in growth across the types of bacteria and across the days for the $1 \mathrm{ml}$ and $2 \mathrm{ml}$ sample respectively.

\section{Discussion}

This study compared the ability of bacterial isolates from crude oil contaminated soil from three different soil locations; the isolated organism which included Serratia marcescens Mb4, Lysinibacillusspp. M2c, Bacillus cereus TPM-23, Proteus mirabilis LS-3 and new unidentified bacterium were subjected to hydrocarbon degradation test. Soil samples were collected from Abia, Anambra, and Rivers state.

The soil $\mathrm{pH}$ ranged from $3.65-6.12$ (Table: 1), the decrease in $\mathrm{pH}$ value was as a result of the accumulation of acid metabolites previous studies the accumulations which has also shown to increases the ability of the heterotrophs microbes present in a crude oil contaminated area, to actively degrade the hydrocarbon present in the soil. This was also reported by Ekhaise and Nkwelle[9]. However, moisture content ranged from $1.6-3.0$ and 4.4 for the control sample. The crude oil contaminated soil sample had lower moisture content when compared to the crude oil free sample, in the research work of Onifade and Abubakar[28]. They suggested that it may be due to the fact that crude oil coated the soil and consequently preventing the penetration of water this was shown in (Table: 1). Total organic carbon TOC ranged from $3.4-4.6$ and $7.1 \%$ for the control sample, the TOC influences many soil characteristics including odour, nutrient holding capacity. The high TOC level obsevered was also seen in the research of Onifade and Abubakar. [28], which proved that the existence of microorganism is also dependent of the level of TOC as one of the major source of nutrient. Table: 2 showed that the bacterial load was high for all samples, this may be because the crude oil contaminated soil favored the growth of the organisms present in the soil sample, similar results were seen in the research conducted by Omotayo et al. [27]. The water holding capacity ranged from $22.4-32.0 \%$ the high value obtained was because of the high organic matter content, which is considered integral in the capacity of a soil to maximize water storage through its effect on creating and stabilizing soil pores and its absorption capacity. Bacterial growth curve which was monitored for 5 days on mineral salt agar at $600 \mathrm{~nm}$ (table: 3 ), the absorbance result ranged from $0.17-0.70$. similarly, strain improvement test was carried out to identify the bacterial isolates that adapted to $1 \mathrm{ml}$ and $2 \mathrm{ml} \%$ of crude oil from the result obtained isolate; A1, A3, B2, B3, C1, C2 adapted very well to $1 \mathrm{ml}$ and $2 \mathrm{ml} \%$ of crude oil with their optical density at $600 \mathrm{~nm}$ ranging from $0.111-0.543$ (Table4). The active isolates were subjected to biodegradation, which was monitored for 14 days in a mineral salt broth, $\mathrm{pH}$ value and absorbance value ranged from $7.2-7.9$ and $0.12-0.60$ respectively. The slight rise in $\mathrm{pH}$ showed that the $\mathrm{pH}$ was at the best range for hydrocarbon degradation, similar result was seen by Onuoha. [29]. Table: 7 showed result for TPH concentration, sample A showed a sharp decrease in TPH concentration which was observed from day $7(454.54 \mathrm{mg} / \mathrm{l})$ and day $14(123.67 \mathrm{mg} / \mathrm{l})$ it showed that Serratia marcescens $\mathrm{Mb} 4$ and Lysinibacillus M2c were able to mineralize the hydrocarbon content to an appreciable level. Ichor, et al. [12], observed similar result, by using bacterial consortium. (Table: 6) showed result of the biochemical characterizations carried out on each isolates, result showed that the isolates were catalase positive and rod shaped and that the gram positive organisms dominated from the result shown. Molecular study using the phylogenetic tree with distance and without distance showed the evolutionary relationship between the isolates. SPSS was used in testing for the significance of growth for the microorganism here one way ANOVA was used to compare growth significance, across the types of bacterial which showed there was no significance, but across the days it showed that there was a significant growth. Since the values obtained were less than the $\alpha$-value $(0.01)$ for both the vapour phase method and adaptation test.

\section{Conclusion}

This study has been able to establish the ability of Lysinibacillus spp. M2c, Serratia marcescensMb4, Proteus mirabilis LS-3, Bacillus aeriusTPM-23, a new unidentified bacterium and unknown isolate to utilize and detoxify crude oil-contaminated soils of Owazangboko in Abia, Aguleriotu in Anambra and Obi-igbo River State, Nigeria. The study showed that a consortium of these organisms in a biodegradation process can increase the rate of hydrocarbon mineralization. The physicochemical characteristics of the soil proved that the soil condition was also conducive for the hydrocarbon degraders.

The study recorded the mineralization of some straight chain hydrocarbons, the bacterial isolates mentioned above were able to mineralize the following hydrocarbons; nonane, octane, decane, nonacosane, triacontane, tetracontane.

\subsection{Contribution to Knowledge}

A new organism was isolated in the course of this study effort will be made to ensure further identification and naming of the isolate.

Studies on biosurfactant production during a biodegradation process can also ensure a more comprehensive understanding on hydrocarbon degradation by microbial consortium to determine a more effective strategy.

This study has experimentally shown that the isolated microbial consortium be used for bioremediation of a crude oil polluted site. This can be made possible by the use of bioaugumentation. 


\subsection{Recommendation}

Efforts should be made, to ensure the conservation of our natural resources. By reducing and monitoring the amount and level of oil spills taking place.

Government should set up Environmental Health Agencies, which will assist in a cleanup exercise in an event of crude oil spill.

Microbial isolates which has proven to have a more and adequate hydrocarbon degradative capabilities should be stored up for future reference and use in a well-designed culture collection center funded by the government.

Researchers should be given access to funds, and scholarship. To enable the advancement of researches in the future.

\section{References}

[1] Abdel-Megeed, A, Al-Hardi, N. and Al-Deyad, S. (2010) Hexadecane degradation by bacterial strains isolated from contaminated soils. African Journal of Biotechnology44: $1684-5315$.

[2] Amu, L. A. O. (2006). A Review of Nigeria's Petroleum Industry. NNPC, Lagos. Department of Petroleum Resources (DPR), Annual Reports, Abuja, Brest, France. pp. 191.

[3] Ayotamuno, M. J., Kogbara, R. B., Ogaji, S. O. T and Probert, S. D. (2006). Bioremediation of a crude oil polluted agricultural-soil at Port Harcourt, Nigeria. Applied Energy83: 1249-1257.

[4] Bundy, J. G., Paton, G. I. and Campell, C. D. (2004). Microbial communities in different soil types do not converge after diesel contamination. Journal of Applied Microbiology 92 (2) $88-276$.

[5] Cheesbrough, M (2000). Biochemical testing of Microorganisms in: Medical Laboratory Manual for Tropical Countries. Vol 11: Microbiology. Cambridge University Press, Pp 58-69.

[6] Chikere, B. O. and Okpokwasili, G. C. (2003). Enhancement of biodegradation of petrochemicals by nutrient supplementation. Nigerian Journal of Microbiology 17 (2): $130-135$.

[7] Chikere, C. B., Okpokwasili and Ichlakor, O. (2009). Characterization of hydrocarbon utilizing bacteria in tropical marine sediments. African journal of Biotechnology 8: (11) $2541-2544$

[8] Diplock, E. E., Mardlin, D. P., Killham, K. S. and Paton, G. I. (2009). Predicting bioremediation of hydrocarbons: Laboratory to field scale. Environmental Pollution 157: 18311840 .

[9] Ekhaise, F. O and Nkwelle, J. (2011). Microbiological and physicochemical Analyses of oil contaminated soil from major motor mechanic workshop in Benin city metropolis, Edo State, Nigeria. Journal of Applied Science 15(4): 597-600.

[10] Ekpo, M. A. and Ekpo, E. I. (2006). Utilization of Bonny light and Bonny Medium crude oil by microorganisms isolated from Qua Iboe River Estuarine. Nigerian Journal of Microbiology 20(1): 832-839.
[11] Gargouri, B., Karray, F., Mhiri, N., Aloui, F., and Sayadi, S. (2011). Application of a continuously stirred tank bioreactor (CSTR) for bioremediation of hydrocarbon-rich industrial wastewater effluents. Journal of Hazardous Materials. 189: 427-434.

[12] Ichor, T, Okerentugba, P. O and Okpokwasili, G. C, (2016). Biodegradation of total petroleum hydrocarbon by a consortium of cyanobacteria Isolated from crude oil polluted brackish water of bodo creeks in Ogoniland, Rivers State. Research Journal of Environmental Toxicology10: 16-27.

[13] Ite, A. E., and Ibok, U. J. (2013). Gas Flaring and Venting Associated with Petroleum Exploration and Production in the Nigeria's Niger Delta. American Journal of Environmental Protection. 1(4). 70-77.

[14] Iturbe, R., Castro, A., Perez, G., Flores, C. and Torres, L. G. (2008). TPH and PAH concentrations in the subsoil of polyduct segments, oil pipelines pumping stations and right of way pipelines from central mexico. Environmental Geology. 55: $1785-1795$.

[15] Iyalla, T. M., (2001). Environmental and hydrogeological mapping; a requirement for the Niger Delta development planning. Technical paper presented at the Nigerian Society of Engineers 'Techincal Session, Port Harcourt, April 12th.

[16] Kampa, M., and Castanas, E. (2008). Human health effects of air pollution. Environmental pollution. 151(2). 362-367.

[17] Kaplan, C. W. and Kitts, C. L. (2004). Bacterial succession in a petroleum land treatment unit. Applied Environmental Microbiology. 70: 1777-1786.

[18] Kawo, A. H. and Bacha, H. Y. (2016). Crude oil degradation by Bacillus and Micrococcus spp. Isolated from soil compost in Kano, Nigeria. Bayero Journal of Pure and Applied Sciences. 9 (1) 108-117.

[19] Kermanshahi, A. P., Karamanev, D. and Margaritis, A. (2005). Biodegradation of petroleum hydrocarbons in an immobilized cell airlift bioreactor. Water Research. 39: 3704-3714.

[20] Kharaka, Y. K., Hanor, J. S., Heinrich, D. H. and Karl, K. T. (2007). Deep fluids in the continents: I. Sedimentary Basins, Treatise on Geochemistry, Oxford: Pergamon. pp 1-48.

[21] Lin, T. C., Pan, P. T. and Cheng, S. S. (2010). Ex-situ bioremediation of oil-contaminated soil. Journal of Hazardous Materials. 176: 27-34.

[22] Margesin, R., Labbé, D., Schinner, F., Greer, C. W. and Whyte, L. G. (2003). Characterization of hydrocarbondegrading microbial populations in contaminated and pristine alpine soil. Applied and Environmental Microbiology. 69: 3085-3092.

[23] Mmom, P. C. (2003). The Niger Delta: A Spatial Perspective to its Development. Zelon Enterprises. Port Harcourt.

[24] Musliu A. and Salawudeen W. (2012). Screening and Isolation of the Soil Bacteria for Ability to Produce Antibiotics. European Journal of Applied Sciences. 4: 211-215.

[25] Ogri, O. R. (2001). A review of the Nigerian Petroleum Industry and the Associated Environmental Problems. The Environmentalist. 21 (1) 11-21.

[26] Ojumu, T. V., Yu, J and Solomon, B. O. (2004). Production of Polyhydroxyalkanoates, a bacterial biodegradable polymer. African Journal of Biotechnology. 3:18-24. 
[27] Omotayo, A. E, Efetie, O. A. Oyetibo, G, Ilori, M. O. and Amund, O. O, (2011). Degradation of aviation fuel by microorganism isolated from tropical polluted soils. International Journal of Biological and Chemical Scicence. 5 (2): 698-708.

[28] Onifade, A. K, and Abubakar, F. A. (2007). Characterization of Hydrocarbon-degrading microorganism isolated from crude oil contaminated soil and remediation of the soil by enhanced natural attenuation. Research Journal of Microbiology. 2 (2): 149-155.

[29] Onuoha, S. C. (2013). Stimulated Biodegradation of Spent Lubricating Motor oil in Soil Amended with Animal droppings. Journal of Natural Science Research. 3 (12) 2224-3186.

[30] Onyeike, E. N. and Osuji, J. O. (2003). Research Techniques in Biological and Chemical Services. Spring field publishers, Ltd. Imo. Pp. 321-327.

[31] Otitoloju, A. A., Are, T. and Junaid, K. A. (2007). Recovery assessment of a refined oil impacted and fire ravaged mangrove ecosystem. Environmental Monitoring Assessment. 127: 353-362.

[32] Paton, G. I., Killham, K., Weitz, H. J. and Semple, K. T. (2005). Biological tools for the assessment of contaminated land. Applied Soil Ecotoxicology. 21: 487-499.

[33] Radwan, S. S., Al-Mailem, D., El-Nemr, I and Salamah, S. (2002). Enhanced remediation of hydrocarbon contaminated desert soil fertilized with organic carbons. International Biodeterioration and Biodegradation. 46: 129-132.

[34] Scheren, P. A., Ibe, A. C.; Janssen, F. J. and Lemmens, A. M. (2002). Environmental pollution in the Gulf of Guinea regional approach, Marine Pollution Bulletin. 44 (7). 633-641.
[35] Sojinu, O. S. S., Wang, J., Sonibare, O. O., and Zang, E. Y. (2010). Polycyclic aromatic hydrocarbons in sediments and soil from oil exploration areas of the Niger Delta, Nigeria. Journal of Hazardous Materials. 174: 641-647.

[36] Stroud, J. L., Paton, G. I., Semple, K. T. (2007). Microbe aliphatic hydrocarbon interactions in soil; implications for biodegradation and bioremediation. Journal of Applied Microbiology. 102: 1239-1253.

[37] Twumasi, Y. and Merem, E. (2006). GIS and remote sensing applications in the assessment of change within a coastal environment in the Niger Delta region of Nigeria. International Journal of Environmental Research and Public Health. 3(1): 98-106.

[38] Umeaku, C. N., Nwadukwe, K. A., Emmyegbe, I. O. and Opara, M. F. (2014). Microorganisms involved in rhizoremediation of crude oil-polluted soils. Free contribution 104. OWSD. Fifth international conference. Woman in science in a quest for sustainability and development. 17-20 September. Mexico.

[39] Umeaku, C. N. (2008). Biochemical Testing of Microorganisms in: Laboratory Practice for Tertiary Institutions. Odus Press, Enugu. ISBN 978-38379-7-4

[40] Worgu, S. O., (2000). Hydrocarbon Exploitation, Environmental Degradation and Poverty in the Niger Delta Region of Nigeria. Sweden Lund University Lumes Programme. pp 221.

[41] Wood, T. A. (2005). Remediation methods for contaminated sites. Journal of Environmental Studies, 2: 126-129. 